\title{
FACTORS THAT INFLUENCE THE GLOBAL QUALITY OF LIFE OF LONG-LIVED OLDER ADULTS (>8O YEARS)
}

\section{Fatores que influenciam a qualidade de vida global de idosos longevos}

\author{
Roumayne Costa ${ }^{a}(\mathbb{1})$, Márcia Carrera ${ }^{a}$ (D), Ana Paula Marquesª (1)
}

OBJECTIVE: To assess the global quality of life and its associated factors in long-lived older adults registered with family health centers. METHODS: This was a cross-sectional, quantitative study based on secondary data from a convenience sample of 100 older adults living in Recife, Brazil. Global quality of life was measured using the two general questions on the World Health Organization Quality of Life instrument. The independent study variables were: sociodemographic characteristics (age, race/skin color, marital status, sex, educational level, individual income, and religion); diagnosed morbidities noted on medical record; depressive symptomology (Geriatric Depression Scale, considering results with scores over 5 as symptomatic); and social support (Lubben Social Network Scale. Independent variables that exhibited statistically significant bivariate associations with the dependent variable at the $5 \%$ level were included in a multivariate model. RESULTS: The results of analyses revealed a mean age of 84.20 years, $77 \%$ of the sample were female, $46 \%$ had spent between 1 and 4 years in education, $63 \%$ were widowed, $76 \%$ had an income equivalent to one to two times the minimum wage, $77 \%$ had systemic arterial hypertension, $34 \%$ had diabetes mellitus, $27 \%$ had cardiovascular disease, $74 \%$ had social support, and 63\% exhibited depressive symptomology. The frequency of satisfactory global quality of life in the sample studied was 35\%. CONCLUSIONS: Concerning the global quality of life, assessed in terms of interviewees' satisfaction with their lives and health in conjunction, the majority of the study population reported not being satisfied. After completing all statistical analyses, factors associated with dissatisfaction were social support, depression, and osteoarthritis. KEYWORDS: adults aged 80 years or over; quality of life; primary healthcare.

OBJETIVO: Avaliar a qualidade de vida global e os fatores associados em idosos longevos assistidos em unidades de saúde da família. MÉTODOS: Trata-se de um estudo transversal, quantitativo, com base em dados secundários, com uma amostra de conveniência de 100 idosos. Foi avaliada a qualidade de vida global por meio das duas questões gerais do instrumento World Health Organization Quality of Life. As variáveis independentes do estudo foram: características sociodemográficas (idade, raça/cor, situação conjugal, sexo, escolaridade, rendimento individual e religião), morbidade diagnosticada em prontuário, sintomatologia depressiva (escala Geriatric Depression Scale, considerando resultados cuja pontuação total foi maior que 5) e apoio social (escala de redes sociais de Lubben). As variáveis independentes que apresentaram associação bivariada estatisticamente significativa a um nível de 5\% com a variável dependente foram incluídas no modelo multivariado. RESULTADOS: Os resultados demonstraram uma média de idade de 84,20 anos, sendo $77 \%$ do sexo feminino, 46\% com escolaridade de um a quatro anos de estudo, 63\% viúvo, 76\% com renda de um a dois salários mínimos, 77\% possuíam hipertensão arterial sistêmica, 34\% com diabetes melito e 27\% apresentavam doença cardiovascular, 74\% tinham apoio social e 63\% com presença de sintomatologia depressiva. A qualidade de vida global satisfatória apresentou uma frequência de 35\% na amostra estudada. CONCLUSÕES: Em relação à qualidade de vida global, avaliada por meio da satisfação dos entrevistados com a vida e a saúde conjuntamente, a maioria da população estudada mostrou-se insatisfeita, tendo como fatores associados, após todas as análises estatísticas utilizadas, o apoio social, a depressão e a osteoartrite.

PALAVRAS-CHAVE: idoso de 80 anos ou mais; qualidade de vida; atenção primária à saúde.

aUniversidade Federal de Pernambuco - Recife (PE), Brazil.

Correspondence data

Roumayne Medeiros Ferreira Costa - Rua Walfrido Lins de Moraes, 367 - Janga - CEP: 53437-100 - Paulista (PE), Brasil. E-mail: roumayne@hotmail.com Received on: 10/21/2019. Accepted on: 11/13/2020.

How to cite this article: Costa R, Carrera M, Marques AP. Factors that influence global quality of life of long-lived older adults (>80 years). Geriatr Gerontol Aging. 2021;15:e0210002. https://doi.org/10.5327/Z2447-212320211900078

https://doi.org/10.5327/Z2447-212320211900078 


\section{INTRODUCTION}

Population aging is increasingly the focus of both scientific research and public policies all over the world. ${ }^{1}$ The aging process is not uniform for all human beings and can be influenced by biopsychosocial factors including discrimination and exclusion, factors related to sex, ethnicity, racism, social and economic conditions, geographic region of origin, and location of residence, ${ }^{2}$ among others.

As older adults become a greater proportion of the population in Brazil, one subject of great interest that is an expanding area of research is the study of quality of life (QoL) and longevity. Quality of life is related to self-esteem and personal well-being, which are linked to a series of factors such as functional capacity, socioeconomic status, emotional state, social interaction, intellectual activity, self-care, family support, own health status, lifestyle, satisfaction with daily activities, and spirituality. ${ }^{3}$

At the end of the 1990s, the World Health Organization (WHO) adopted the term "active aging", which consists of a process of consolidation of opportunities for health, participation, and safety, with the objective of improving QoL as people age. This approach to aging offers people a different perspective on their capabilities, in terms of their physical, social, and mental well-being over the course of a lifetime, enabling them to participate in society in accordance with their needs, interests, and capabilities. ${ }^{4}$

Research involving subjects related to aging and $\mathrm{QoL}$ indicate a need to understand preventative behaviors targeting factors that modify this period, such as disease for example, and also possible changes affecting lifestyle imposed by this new behavior, in addition to possible changes and transformations of common-sense knowledge. Issues such as finding virtues in age, prolonging youth, and aging with good perceived QoL are dealt with in many different disciplines. ${ }^{5}$

Therefore, measuring how people are reaching these additional years of life and how they and living them has become an important objective, including analysis of perceived QoL among these older adults. One study conducted with younger and long-lived older adults found that this group had good perceived QoL. The younger older adults had better perceived QoL in the physical and social relationships domains and also in relation to "intimacy" than the older subset. In turn, long-lived older adults had better perceived QoL for "death and dying" when compared to the younger older adults. ${ }^{5}$

Studies of QoL among older people have become of interest in Brazil, since longevity is not always accompanied by good QoL. This is thus a relevant public health problem, since life expectancy is increasing in the country and because this population's living conditions are unsatisfactory, making it a concern among those in government. Psychosocial, economic, and political consequences are all part of the problem, since older adults are faced with embarrassing and awkward situations and are the victims of prejudice because of the period of life they have arrived at. ${ }^{5,6}$

Earlier studies by Peteet and Khorami, cited by Nunes et al., ${ }^{7}$ found evidence that many patients have sought to improve QoL by employing spiritual and religious resources to improve their life satisfaction. Another study illustrates the importance of religion and of practicing it in relation to QoL, finding that 50 individuals aged from 65 to 86 years considered religiosity to be extremely important in their lives, giving them the strength to cope with problems, loss, and struggles.

A study by Clementino and Goulart, ${ }^{8}$ found a positive relationship between QoL in advancing age and physical activity and a negative relationship with excess weight and poor nutritional status. Their objective was to determine how QoL impacts on health promotion in older adults. Different segments of society are thus challenged to produce knowledge that results in understanding of the factors that directly affect QoL in this age group.

Another study cites factors related to successful aging in long-lived adults, showing that sociodemographic variables are the factors most investigated. Correlations were positive for younger older adults; male sex; higher educational levels; married marital status; better cognition scores; lower risk of falls; lower number of medications for chronic diseases; low prevalence of comorbidities; and lower nutritional risk. The variability of findings among the articles analyzed in that study and the small number of publications found show that the subject of QoL in long-lived older adults is still a considerable challenge. ${ }^{9}$

In view of all of the above, the objective of this study was to assess global QoL and factors associated with it in longlived older adults registered with family health centers (FHC).

\section{METHODS}

This was a cross-sectional, quantitative study of secondary data collected for the project "Successful aging in longlived older adults and associated factors". This type of study offers advantages such as low cost, shorter duration, and easier access to a sample representative of a population, in addition to offering a good source of hypotheses..$^{10}$ For the purposes of this study, long-lived older adults were those aged 80 and over. The study population comprised 485 long-lived older adults of both sexes living in the community within the area encompassed by microregion 4.2 of the city of Recife, PE, Brazil, who were registered with the local FHCs. 
The sample size was 100 older adults, after definition of exclusion criteria such as institutionalized older adults; those receiving home care; and those with cognitive incapacity. The sample was also selected according to the availability of data and the objectives proposed. Records that contained information on the dependent variable global QoL of long-lived older adults, obtained in answer to the two general questions on the World Health Organization Quality of Life instrument (WHOQOL-BREF), were selected from the database.

The independent study variables were: sociodemographic characteristics (age, race/skin color, marital status, sex, educational level, individual income, and religion); diagnosed morbidities noted on medical record; depressive symptomology (Geriatric Depression Scale [GDS], considering results with scores over 5 as symptomatic); and social support (Lubben Social Network Scale [LSNS], on which scores lower than 12 identify individuals with deficient support networks and risk of social isolation).

Data were organized using a database built using EPI INFO version 3.5.3. After double-input data entry, data were checked to rule out possible inconsistencies. For analysis, the database created in EPI INFO was exported to the Package for Social Sciences for Windows, version 16.0.

A descriptive analysis of the distributions of the population was conducted, calculating absolute and relative frequencies for categorical variables and minimum and maximum values, means, medians, and standard deviation for continuous variables. Tests of hypotheses were run to test for associations between the dependent variable and the independent variables. Independent variables that exhibited statistically significant bivariate associations with the dependent variable at the $5 \%$ level were included in a multivariate model. The model's percentage accuracy was calculated in order to determine how close to reality the results obtained were. The chi-square test and Fisher's exact test were also used.

The study is nested within a research project entitled "Successful aging in long-lived older adults and associated factors", for which data were collected after free and informed consent forms were signed, and which has been registered with and approved by the Human Research Ethics Committee at the Universidade Federal de Pernambuco (CAAE no 34900514.0.0000.5208), in compliance with Ministry of Health resolution 466/12 and in accordance with the ethical principles set out in the Helsinki Declaration (2000).

\section{RESULTS}

The mean age of the sample was 84.20 years, ranging from 80 to 94 years $( \pm 3.15)$. The main characteristics of the sample investigated were as follows. Sociodemographic characteristics: $77 \%$ were female, $46 \%$ had spent from 1 to 4 years in education, $63 \%$ were widowed, $76 \%$ had an income equivalent to one to two times the minimum wage. Morbidity diagnosed and noted on medical record: the most prevalent disease was systemic arterial hypertension, 77\%; followed by diabetes mellitus, $34 \%$, and cardiovascular disease, $27 \%$. Additionally, $74 \%$ had social support; and $63 \%$ had depressive symptomology.

Global QoL was defined as follows:

- Satisfactory: satisfaction with both life and with self-perceived health;

- Unsatisfactory: all other combinations.

Global QoL was classified using the first two questions on the WHOQOL-BREF, which cover self-assessed satisfaction with QoL and self-perceived health. According to this approach, the frequency of satisfactory global $\mathrm{QoL}$ in the sample studied was $35 \%$, as shown in Table 1 .

Based on this classification, we analyzed the relationships between questions on global $\mathrm{QoL}$ and the independent variables, as shown in Tables 2 and 3 .

Significant associations were found with the variables social support and depressive symptomology. This indicates that satisfaction with global QoL is influenced by these variables, as shown in Table 2.

It can be observed in Table 3 that there were also associations with the variables osteoporosis $(\mathrm{OP})$ and osteoarthrosis $(\mathrm{OA})$. This indicates that satisfaction with global QoL is influenced by these variables.

A multivariate logistic model was used to conduct a multivariate analysis of the relationship between global QoL and the independent variables that had exhibited significant associations in the bivariate analyses. The results are shown in Tables 4 and 5 .

It can be observed in Table 4 that the estimate of the older adults for classification 1 of satisfaction had accuracy of $77.10 \%$, whereas for the older adults classified in row 2, accuracy was $73.80 \%$. In other words, the model is very good for estimating global life satisfaction.

The earlier estimates are used to construct the logistic regression equation to estimate scores for older adults with the

Table 1. Global quality of life (Recife, Pernambuco, Brazil, 2018).

\begin{tabular}{l|c|c} 
& Frequency & $\%$ \\
\hline Satisfactory & 35 & 35 \\
\hline Unsatisfactory & 65 & 65 \\
\hline Total & 100 & 100 \\
\hline
\end{tabular}


characteristics studied. It can be observed that, except for OP, all of the variables identified as significant in bivariate analyses are significant to the $5 \%$ level and that none of the confidence intervals include zero. In general, the model offers good accuracy for estimating the dependent variable global QoL.

\section{DISCUSSION}

The female predominance (77\%) in the sample studied is in line with population-based surveys and also with studies of specific populations of older adults, ${ }^{6,11}$ and coincides with the percentage reported by Nunes et al. ${ }^{7}$

Table 2. Classification of global quality of life, by sociodemographic conditions, social support, and depressive symptomology (Recife, Pernambuco, Brazil, 2018).

\begin{tabular}{|c|c|c|c|c|c|c|}
\hline & & Satisfactory & $\%$ & Unsatisfactory & $\%$ & p-value \\
\hline \multirow{2}{*}{ Age group } & $<84$ years & 17 & 36.20 & 30 & 63.80 & \multirow{2}{*}{0.81} \\
\hline & $\geq 84$ years & 18 & 34.00 & 35 & 66.00 & \\
\hline \multirow{2}{*}{ Sex } & Male & 8 & 34.80 & 15 & 65.20 & \multirow{2}{*}{0.98} \\
\hline & Female & 27 & 35.10 & 50 & 64.90 & \\
\hline \multirow{4}{*}{ Marital status } & Single(a) & 2 & 20.00 & 8 & 80.00 & \multirow{4}{*}{0.36} \\
\hline & Married/has partner & 6 & 27.30 & 16 & 72.70 & \\
\hline & Widowed & 24 & 38.10 & 39 & 61.90 & \\
\hline & Separated /divorced & 3 & 60.00 & 2 & 40.00 & \\
\hline \multirow{4}{*}{$\begin{array}{l}\text { Educational level } \\
\text { (years) }\end{array}$} & Illiterate & 10 & 33.30 & 20 & 66.70 & \multirow{4}{*}{0.64} \\
\hline & $1-4$ years & 18 & 39.10 & 28 & 60.90 & \\
\hline & $5-8$ years & 5 & 25.00 & 15 & 75.00 & \\
\hline & $9-11$ years & 2 & 50.00 & 2 & 50.00 & \\
\hline \multirow{4}{*}{ Race/skin color } & White & 12 & 35.30 & 22 & 64.70 & \multirow{4}{*}{0.71} \\
\hline & Black & 9 & 45.00 & 11 & 55.00 & \\
\hline & Yellow & 1 & 25.00 & 3 & 75.00 & \\
\hline & Mixed race & 13 & 31.00 & 29 & 69.00 & \\
\hline \multirow{4}{*}{ Religion } & Catholic & 23 & 31.90 & 49 & 68.10 & \multirow{4}{*}{0.45} \\
\hline & Evangelical & 10 & 40.00 & 15 & 60.00 & \\
\hline & Spiritualist & 1 & 50.00 & 1 & 50.00 & \\
\hline & Atheist & 1 & 100 & 0 & 0 & \\
\hline \multirow{4}{*}{ Income } & $\begin{array}{l}\text { Less than } 1 \text { times the } \\
\text { minimum wage }\end{array}$ & 5 & 33.30 & 10 & 66.70 & \multirow{4}{*}{0.72} \\
\hline & $\begin{array}{l}1-2 \text { times the } \\
\text { minimum wage }\end{array}$ & 28 & 36.80 & 48 & 63.20 & \\
\hline & $\begin{array}{l}2-4 \text { times the } \\
\text { minimum wage }\end{array}$ & 2 & 28.60 & 5 & 71.40 & \\
\hline & $\begin{array}{l}\text { More than } 4 \text { times the } \\
\text { minimum wage }\end{array}$ & 0 & 0 & 2 & 100 & \\
\hline \multirow{3}{*}{ Perceived status } & Excellent & 26 & 35.60 & 47 & 64.40 & \multirow{3}{*}{0.42} \\
\hline & Excellent*Good & 0 & 0 & 3 & 100 & \\
\hline & Good & 9 & 37.50 & 15 & 62.50 & \\
\hline \multirow{2}{*}{ Social support } & Yes & 32 & 43.20 & 42 & 56.80 & \multirow{2}{*}{0.003} \\
\hline & No & 3 & 11.50 & 23 & 88.50 & \\
\hline \multirow{2}{*}{$\begin{array}{l}\text { Depressive } \\
\text { symptomology }\end{array}$} & Yes & 5 & 13.50 & 32 & 86.50 & \multirow{2}{*}{0.001} \\
\hline & No & 30 & 47.60 & 33 & 52.40 & \\
\hline
\end{tabular}


Santos et al. ${ }^{11}$ highlighted the predominance of females in all age groups, which can be explained by the historic process of greater male mortality throughout life; mortality which is linked with lifestyle habits and healthcare and which is a profile that is observed worldwide. As aging progresses, therefore, it is found that women live longer than men, become widows earlier, more frequently reach advanced ages, and survive longer at older ages.

According to the Brazilian Institute of Geography and Statistics (IBGE - Instituto Brasileiro de Geografia e Estatística) ${ }_{1}^{12}$ projected life expectancy of Brazilians at birth, which is currently estimated at 72.70 years for men and 79.80 years for women, will reach 77.90 years for men and 84.20 years for women in 2060. Thus, in the Brazilian setting, there is a tendency for women to reach older ages than men, with a resulting predominance of elderly women, since mortality affects a greater proportion of men, characterizing the phenomenon of feminization of old age.

Analysis of the correlation between sex and the different QoL scores for the older adults assessed by the WHOQOLBREF showed that there was no significant association with QoL, which is a result that was also found by Magalhães. ${ }^{13}$ However, it is also important to mention Medeiros and Morais ${ }^{14}$ who state that one probable explanation is the female population's assiduousness to services, linked to greater concern with health issues.
With relation to marital status, the sample contained a higher percentage of widows (63\%), in contrast with the investigation conducted by Magalhães, ${ }^{13}$ in which the proportion of married participants exceeded that of widows. Different results were also found by Lopes et al., ${ }^{6}$ who observed a predominance of married people among long-lived older adults (42.50\%). In turn, Torres et al. ${ }^{3}$ were closer to the present study, reporting that $46.20 \%$ of the older population studied were widows, as were Nunes et al., ${ }^{7}$ with $63 \%$ of widows.

When marital status and QoL were compared, no statistical association was found, confirming results reported by Magalhães ${ }^{13}$ and Porciúncula et al. ${ }^{15}$ since they point out that widowed older adults have constant company from relatives, which is consistent with maintenance of QoL.

With regard to the low educational level observed in the present study, $46 \%$ had spent from 1 to 4 years in education. A similar result was observed by Porciúncula et $a 1 .{ }^{15}$ who found that a majority of older adults had no education or had only

Table 4. Classification of global quality of life (Recife, Pernambuco, Brazil, 2018).

\begin{tabular}{|c|c|c|c|}
\hline & & $\mathrm{n}$ & Accuracy \\
\hline \multirow{2}{*}{ Global QoL } & Satisfactory & 35 & 77.10 \\
\hline & Unsatisfactory & 65 & 73.80 \\
\hline \multicolumn{2}{|c|}{ Total accuracy } & 100 & 75.00 \\
\hline
\end{tabular}

Table 3. Classification of global quality of life by diagnosed morbidities recorded on medical records (Recife, Pernambuco, Brazil, 2018).

\begin{tabular}{|c|c|c|c|c|c|c|}
\hline & & Satisfactory & $\%$ & Unsatisfactory & $\%$ & p-value \\
\hline \multirow{2}{*}{$\begin{array}{l}\text { Systemic arterial } \\
\text { hypertension }\end{array}$} & Absent & 9 & 39.13 & 14 & 60.87 & \multirow{2}{*}{0.63} \\
\hline & Present & 26 & 33.77 & 51 & 66.23 & \\
\hline \multirow{2}{*}{ Diabetes mellitus } & Absent & 27 & 40.91 & 39 & 59.09 & \multirow{2}{*}{0.08} \\
\hline & Present & 8 & 23.53 & 26 & 76.47 & \\
\hline \multirow{2}{*}{ Cardiovascular disease } & Absent & 27 & 36.99 & 46 & 63.01 & \multirow{2}{*}{0.49} \\
\hline & Present & 8 & 29.63 & 19 & 70.37 & \\
\hline \multirow{2}{*}{ Osteoporosis } & Absent & 31 & 40.26 & 46 & 59.74 & \multirow{2}{*}{0.04} \\
\hline & Present & 4 & 17.39 & 19 & 82.61 & \\
\hline \multirow{2}{*}{ Osteoarthrosis } & Absent & 33 & 42.31 & 45 & 57.69 & \multirow{2}{*}{0.004} \\
\hline & Present & 2 & 9.09 & 20 & 90.91 & \\
\hline \multirow{2}{*}{ Neurological diseases } & Absent & 34 & 35.79 & 61 & 64.21 & \multirow{2}{*}{0.47} \\
\hline & Present & 1 & 20.00 & 4 & 80.00 & \\
\hline \multirow{2}{*}{ Respiratory diseases } & Absent & 32 & 35.16 & 59 & 64.84 & \multirow{2}{*}{0.91} \\
\hline & Present & 3 & 33.33 & 6 & 66.67 & \\
\hline \multirow{2}{*}{ Neoplasms } & Absent & 35 & 36.08 & 62 & 63.92 & \multirow{2}{*}{0.19} \\
\hline & Present & 0 & 0 & 3 & 100 & \\
\hline
\end{tabular}


completed primary school, and that a small proportion had higher education or postgraduate education. With regard to this variable, there was no correlation between educational level and QoL, in common with the aforementioned study.

With regard to the incomes of these Brazilian older adults, we found that $76 \%$ had an income from one to two times the minimum wage, although the correlation with QoL was not statistically significant. Lopes et al. ${ }^{6}$ reported in their results that the family income of older adults is generally concentrated in the range of one to three times the minimum wage, since the majority are retired and do not have additional sources of income.

Studies of income and family composition in Brazil have detected large numbers of vulnerable older adults. ${ }^{16}$ This finding, which is associated with older people's wellbeing, reflects an important source of compromise, since older people with lower incomes are more challenged by problems related to their wellbeing.

With regard to depressive symptomology, a study conducted by Silva et al. ${ }^{17}$ with long-lived older adults registered with the Family Health Strategy in the town of Marilia, SP, Brazil, reported a $29.50 \%$ frequency of depression, which contrasts with the data observed in the present study, in which depressive symptomology was present in $63 \%$ of the long-lived older adults studied. The same authors state that negative events, social problems, and the physical diseases and disabilities that are common in this age group increase the likelihood of developing depression.

According to Silva, ${ }^{5}$ assessing depressive symptomology using internationally-recognized scale can contribute to better detection of depression cases in this age group. In her study, $49 \%$ of the individuals assessed had depression. Of these, $36.30 \%$ were classified as having mild depression and $12.7 \%$ had severe depression.

Rosset et al. ${ }^{18}$ claim that domestic and international studies show that advancing age is associated with increased rates of depressive symptoms among older adults in general. Nóbrega et al. ${ }^{19}$ state that experiencing loneliness can indicate an inadequate social network and is one of the risk factors for depression most cited by researchers. Presence of depressive symptomology was also observed in studies by Lopes et al. ${ }^{6}$ Nunes et al. ${ }^{7}$ did not identify depression as statistically significant in their research.

On the subject of social support as a determinant factor of QoL in long-lived older adults, our study found that $74 \%$ of the older adults interviewed had social support, which was not observed in a study by Nogueira et al., ${ }^{20}$ who discuss a positive association between loss of functional capacity in long-lived older adults and a lack of social support, manifest as not visiting relatives and/or friends at least once a week and as not participating in social projects and not participating in social events, showing that functional capacity is a factor that impacts on QoL in this segment of the population.

Navarro et al. ${ }^{21}$ reported that, $22.5 \%$ of long-lived adults did not go out at least once a week, which was a significantly higher percentage when compared with younger older adults. Also according to these authors, a study conducted in the town of Palmeira das Missões, RS, Brazil, to assess QoL and cognitive level among older adults who were members of four groups of older adults who met weekly, with activities such as craft workshops, dancing, trips, physical exercises, and socialization, found that the percentage of the oldest older adults who attended was lower, with predominance of older adults aged from 60 to 69 years and 70 to 79 years. Studies of the same subject have stressed the importance of social interactions for older adults. It is through daily interactions that older adults become conscious of their roles as social actors and their ability to contribute to society.

With regard to the positive impact of social support on QoL in long-lived adults, the authors Nunes et al. ${ }^{7}$ and Santos et al. ${ }^{11}$ are in agreement. According to Nogueira et al., ${ }^{20}$ interaction with family, neighbors, and friends, supplemented by participation in social groups, such as groups for older people, enables older people to adapt to this phase of life with greater tranquility, to experience more pleasure, to perform activities that were not previously habitual, and to interact with other people, thereby expanding their network of interpersonal relations, reducing loneliness and reintegrating into

Table 5. Estimations for variables used to construct logistic regression equation (Recife, Pernambuco, Brazil, 2018).

\begin{tabular}{l|c|c|c|c} 
& Significance & Exponent (B) & \multicolumn{2}{|c}{$95 \% \mathrm{Cl}$} \\
\hline Social support & 0.05 & 4.06 & 0.03 & 16.05 \\
\hline Depressive symptoms & 0.01 & 0.23 & 1.28 & 0.75 \\
\hline Osteoarthrosis & 0.02 & 6.67 & & 34.79 \\
\hline Constant & 0.57 & 0.35 & & \\
\hline
\end{tabular}

95\% Cl: 95\% confidence interval. 
society. Jorge et al. ${ }^{22}$ state that socialization groups can help to prevent deterioration, promote health, and improve the QoL of older adults.

With regard to the most prevalent diseases, systemic arterial hypertension (77\%), diabetes mellitus (34\%), and cardiovascular disease $(27 \%)$ were the most common. It was also observed that there was an association between QoL and OA. Nunes et al. ${ }^{7}$ also found these morbidities in their study, with the exception of hypertension. Porciúncula et al. ${ }^{15}$ reported that arterial hypertension, diseases affecting the spine and/or back pain, and problems affecting vision were the most common conditions. Also with regard to health problems, Mendonça et al. ${ }^{23}$ observed that $92 \%$ of dependent older adults had health problems, the most frequent of which were systemic arterial hypertension (SAH) (32\%) and SAH in conjunction with diabetes mellitus (16\%).

Each person makes judgments on their own global QoL and this involves several different aspects. Global QoL was self-assessed as satisfactory by $35 \%$ of these older adults, considering both life satisfaction and self-perceived health. This percentage is considered very good, when related to a population of long-lived older adults, comprising a significant result, since there are many different factors that negatively impact on the health of this population's QoL. Nogueira et al. ${ }^{20}$ observed results showing that QoL was considered good by $40.10 \%$ and very good by $25.40 \%$ of long-lived older adults. Oliveira et al. ${ }^{24}$ observed higher scores for perceived QoL classified as very good. For self-perceived health, Jorge et al..$^{22}$ report that $43.10 \%$ of their sample described their health as regular and the same percentage rated their health as good.

Lopes et al. ${ }^{6}$ indicate that the QoL of long-lived older adults was compromised in the psychological and environment domains, but do not report compromise of global QoL. Santos et al. ${ }^{11}$ found that the older adults who participated in the study had relatively good perceived QoL, which is related to the data observed in the sample studied for global QoL, classified as satisfactory by $35 \%$.

Successful aging is related to healthy aging, considering psychological, social, and environmental factors that modify the QoL of these people. Alves ${ }^{25}$ states that older adults with better wellbeing also have higher levels of mental health and higher perceived social support, contributing to a positive assessment of QoL. According to Knappe et al., ${ }^{9}$ in terms of factors associated with successful aging, there is unanimity on the biomedical component, which includes absence of significant diseases in addition to conserved functionality and cognition,.
A study conducted by Mendonça et al..$^{23}$ observed that the older adults assessed exhibited better mean QoL in domains involving social relations, directly linked to the satisfaction that older adults have with their relatives, friends, support, and sexual activity. Quality of life was also rated positively in the environment domain, which is related to the environment in which each respondent lives. These authors state that other studies also used the WHOQOL-BREF to assess QoL in older adults and found better scores in these domains. In contrast, advancing age, functional changes, the impact that a disease can have on the life of an older person, the changed capacity to perform daily activities, and physical and emotional compromise all had negative impacts on quality of life in this population.

With regard to health, which is an issue that belongs to the general QoL domain, Nogueira et al. ${ }^{20}$ reported that the majority of older adults reported that they were satisfied. A study conducted by Jóia et al. ${ }^{26}$ observed that being in good health was very important for positive QoL. Thus, good health can very often equate to good QoL. In our study, the sample of long-lived adults had certain diagnosed morbidities noted on their medical records (the most prevalent diseases were $77 \%$ systemic arterial hypertension, followed by $34 \%$ diabetes mellitus, and $27 \%$ cardiovascular disease), which coincides with the aforementioned study, concluding that these older adults may have their QoL level affected, even though the study observed 35\% satisfaction with QoL despite these morbidities. Knappe et al. ${ }^{9}$ state that very long-lived people, including centenarians, have high levels of subjective health and happiness.

One limitation of this study is the design employed, which has the inherent disadvantages of the impossibility of determination of cause-effect relationships and ignorance of past factors and of duration of current morbidities in the study population. Considering the limitations of the type of study and the small number of long-lived older adults who comprised the sample, the need for additional studies should be emphasized.

\section{CONCLUSIONS}

With relation to global QoL, assessed in terms of interviewees' satisfaction with both their health and their lives in general, the majority of the study population was unsatisfied. After all of the statistical analyses employed, the factors associated with global QoL were social support, depression, and $\mathrm{OA}$. 


\section{ACKNOWLEDGEMENTS}

We are grateful to the staff at the UFPE Gerontology Department for their help with conducting this research.

\section{CONFLICTS OF INTEREST}

We declare that there are no conflicts of interests related to this study.

\section{FUNDING}

None.

\section{AUTHORS' CONTRIBUTIONS}

RC: conceptualization, planning, analysis and interpretation of data, writing the draft or critical review of its content, approval of the final version of the manuscript. MC: conceptualization, planning, analysis and interpretation of data, writing the draft or critical review of its content, approval of the final version of the manuscript. APM: conceptualization, planning, analysis and interpretation of data, writing the draft or critical review of its content, approval of the final version of the manuscript.

\section{REFERENCES}

1. Brito TA, Fernandes MH, Coqueiro RS, Jesus CS. Quedas e capacidade funcional em idosos longevos residentes em comunidade. Texto Contexto - Enferm. 2013;22(1):43-51. https://doi.org/10.1590/ S0104-07072013000100006

2. Sampaio LS, Silva Neto DG, Reis LA, Lauton MAR, Reis LA, Santos AO, et al. Condições sociodemográficas e de saúde de idosos residentes em domicílio no município de Jequié-BA. Rev Bras Geriatr Gerontol. 2009;12(2):267-74. https://doi.org/10.1590/1809-9823.2009.12029

3. Torres GV, Reis LA, Reis LA, Fernandes MH. Qualidade de vida e fatores associados em idosos dependentes em uma cidade do interior do Nordeste. J Bras Psiquiatr. 2009;58(1):39-44. https:// doi.org/10.1590/S0047-20852009000100006

4. Azevedo MSA. O envelhecimento ativo e a qualidade de vida: uma revisão integrativa [dissertação]. Porto: Escola Superior de Enfermagem do Porto; 2015.

5. Silva LM. Envelhecimento e qualidade de vida para idosos: um estudo de representações sociais [dissertação]. João Pessoa: Universidade Federal da Paraíba; 2011.

6. Lopes AOS, Pimentel SD, Oliveira AS, Silva DS, Reis LA. Qualidade de vida de idosos longevos segundo sua caracterização sóciodemográfica. Políticas de envelhecimento populacional. Ponta Grossa: Atena; 2019.

7. Nunes MGS, Leal MCC, Marques APO, Mendonça SS. Idosos longevos: avaliação da qualidade de vida no domínio da espiritualidade, da religiosidade e de crenças pessoais. Saúde Debate. 2017;41(115):110215. https://doi.org/10.1590/0103-1104201711509

8. Clementino MD, Goulart, RMM. Imagem corporal, estado nutricional e qualidade de vida em idosos longevos. Rev Bras Geriatr Gerontol. 2019;22(6):e190181. http://doi.org/10.1590/1981-22562019022.190181

9. Knappe MFL, Santo ACGE, Leal MCC, Marques APO. Envelhecimento bem-sucedido em idosos longevos: uma revisão integrativa. Geriatr Gerontol Aging. 2015;9(2):66-70. http://doi.org/10.5327/Z2447-2115201500020006

10. Sitta El, Arakawa AM, Caldana ML, Peres, SHCS. A contribuição de estudos transversais na área da linguagem com enfoque em afasia. Revista CEFAC. 2010;12(6):1059-66. https://doi.org/10.1590/ S1516-18462010005000086

11. Santos PM, Souza BC, Marinho A, Mazo GZ. Percepção de qualidade de vida entre idosos jovens e longevos praticantes de hidroginástica. Rev Bras Qual Vida. 2013;5(1):1-11. http://doi.org/10.3895/S2175-08582013000100001

12. Instituto Brasileiro de Geografia e Estatística (IBCE). 1 em cada 4 brasileiros terá mais de 65 anos em 2060, aponta IBGE. Available from: https:/g1.globo. com/economia/noticia/2018/07/25/1-em-cada-4-brasileiros-tera-maisde-65-anos-em-2060-aponta-ibge.ghtml. Accessed in Aug 26, 2018.

13. Magalhaes APN. Qualidade de vida: Percepção dos participantes da Associação dos aposentados, pensionistas e idosos de Arapiraca Alagoas [dissertação]. Recife: Programa integrado de Pós-Graduação em Saúde Coletiva, UFPE; 2009.
14. Medeiros SG, Morais FRR. Organização dos serviços na atenção à saúde da idosa: percepção de usuárias. Interface (Botucatu). 2015;19(52):109-19. http://doi.org/10.1590/1807-57622014.0264

15. Porciúncula R, Carvalho EF, Barreto KML, Leite VMM. Perfil socioepidemiológico e autonomia de longevos em Recife-PE, Nordeste do Brasil. Rev Bras Geriatr Gerontol. 2014;17(2):315-25. https://doi.org/10.1590/S1809-98232014000200009

16. Tomomitsu MRSV, Perracini MR, Neri AL. Influência de gênero, idade e renda sobre o bem-estar de idosos cuidadores e não cuidadores. Rev Bras Geriatr Gerontol. 2013;16(4):663-80. https://doi.org/10.1590/ S1809-98232013000400002

17. Silva SPZ, Marin MJS, Rodrigues MR. Condições de vida e de saúde de idosos acima de 80 anos. Rev Gaúcha Enferm. 2015;36(3):42-8. https://doi.org/10.1590/1983-1447.2015.03.50263

18. Rosset I, Roriz-Cruz M, Santos JLF, Haas VJ, Fabrício-Wehbe SCC, Rodrigues RAP. Diferenciais socioeconômicos e de saúde entre duas comunidades de idosos longevos. Rev Saude Publica. 201 1;45(2):391400. https://doi.org/10.1590/S0034-89102011000200018

19. Nóbrega IRAP, Leal MCC, Marques APO, Vieira JCM. Fatores associados à depressão em idosos institucionalizados: revisão integrativa. Saúde Debate. 2015;39(105):536-50.https://doi.org/10.1590/0103-110420151050002020

20. Nogueira SL, Ribeiro RCL, Rosado LEFPL, Franceschini SCC, Ribeiro AQ, Pereira ET. Fatores determinantes da capacidade funcional em idosos longevos. Rev Bras Fisioter. 2010;14(4):322-9. https://doi. org/10.1590/S1413-35552010005000019

21. Navarro JHN, Andrade FP, Paiva TS, Silva DO, Gessinger CF, Bós AJG. Percepção dos idosos jovens e longevos gaúchos quanto aos espaços públicos em que vivem. Ciênc Saúde Coletiva. 2015;20(2):461-70. https://doi.org/10.1590/1413-81232015202.03712014

22. Jorge MSG, Lima WG, Vieira PR, Vogelmann SC, Myra RS, Wibelinger LM. Caracterização do perfil sociodemográfico, das condições de saúde e das condições sociais de idosos octogenários. Rev Saúde Pesq. 2017;10(1):6173. https://doi.org/10.17765/2176-9206.2017v10n1p61-73

23. Mendonça MA, Marinho MS, Santana ES, Chaves RN, Oliveira AS, Lopes AOS, et al. Avaliação da qualidade de vida de idosos dependentes no município de Vitória da Conquista/BA. Fisioter Brasil. 2018;19(5):624-30. http://doi.org/10.33233/fb.v19i5.2236

24. Oliveira MA, Ribeiro HF, Costa NP. Qualidade de vida de idosos amazônicos que participam de um grupo de convivência. Enferm Foco. 2019;10(3):58-63.

25. Alves LMT. Apoio Social, Saúde Mental e Bem-Estar em Idosos Institucionalizados e Não Institucionalizados [dissertação]. Porto: Faculdade de Ciências Humanas e Sociais da Universidade Fernando Pessoa; 2016.

26. Jóia LC, Ruiz T, Donalisio MR. Condições associadas ao grau de satisfação com a vida entre a população de idosos. Rev Saúde Pública. 2007;41(1):131-8. https://doi.org/10.1590/S0034-89102007000100018 